Derivation of Groundwater Threshold Values for Analysis of Impacts Predicted at Potential Carbon Sequestration Sites

3

4

G. V. Last, Corresponding author

Pacific Northwest National Laboratory

902 Battelle Boulevard

Richland, WA, 99354, United States

Tel.: +1 509 371-7080

Fax: $+1509371-7344$

george.last@pnnl.gov

12 


\section{Derivation of Groundwater Threshold Values for Analysis of Impacts \\ 2 Predicted at Potential Carbon Sequestration Sites}

3

4 G. V. Last*, C. J. Murray ${ }^{\mathrm{a}}$, and Y Bott ${ }^{\mathrm{b}}$

5 Pacific Northwest National Laboratory, 902 Battelle Boulevard, Richland, WA, 99354, United States

6 *Corresponding Author. george.last@ pnnl.gov; Tel.: +1 509 371-7080; fax: +1 509 371-7344

$7 \quad{ }^{\mathrm{a}}$ Chris.Murray@pnnl.gov; Tel.: +1 509 371-7090; fax: +1 509 371-7344

8 byi-ju.bott@pnnl.gov; Tel.: +1 585 473-5042

10 Abstract

11

12 The U.S. Department of Energy's (DOE's) National Risk Assessment Partnership (NRAP) Project is

13 developing reduced-order models to evaluate potential impacts to groundwater quality due to carbon

14 dioxide $\left(\mathrm{CO}_{2}\right)$ or brine leakage, should it occur from deep $\mathrm{CO}_{2}$ storage reservoirs. These efforts targeted

15 two classes of aquifer - an unconfined fractured carbonate aquifer based on the Edwards Aquifer in

16 Texas, and a confined alluvium aquifer based on the High Plains Aquifer in Kansas. Hypothetical

17 leakage scenarios focus on wellbores as the most likely conduits from the storage reservoir to an

18 underground source of drinking water (USDW). To facilitate evaluation of potential degradation of the

19 USDWs, threshold values, below which there would be no predicted impacts, were determined for each of

20 these two aquifer systems. These threshold values were calculated using an interwell approach for

21 determining background groundwater concentrations that is an adaptation of methods described in the

22 U.S. Environmental Protection Agency's Unified Guidance for Statistical Analysis of Groundwater

23 Monitoring Data at RCRA Facilities. Results demonstrate the importance of establishing baseline

24 groundwater quality conditions that capture the spatial and temporal variability of the USDWs prior to

$25 \mathrm{CO}_{2}$ injection and storage.

26

27 Key Words

28

29 Carbon storage; $\mathrm{CO}_{2}$ and bine leakage; Underground sources of drinking water; Groundwater quality;

30 Threshold values; Predicted groundwater impacts 


\section{$2 \quad 1$ Introduction}

4 Geologic storage of carbon dioxide $\left(\mathrm{CO}_{2}\right)$ is a promising tool in the strategy for reducing atmospheric

5 emissions of $\mathrm{CO}_{2}$, thereby mitigating climate change (Hepple and Benson, 2005; IPCC, 2005; NETL,

6 2012). All signs continue to point to the necessity and viability of carbon capture and storage (CCS) as a

$7 \quad \mathrm{CO}_{2}$ abatement technology (IEA, 2014). Long-term storage of $\mathrm{CO}_{2}$ in deep geologic formations requires

8 careful assessment of the reservoir integrity, potential leakage pathways, and consideration of potential

9 impacts on the atmosphere and shallow groundwater (Herzog et al., 2003; Benson and Cole, 2008;

10 Bielicki et al., 2014).

12 The U.S. Department of Energy's (DOE) Office of Fossil Energy established the National Risk

13 Assessment Partnership (NRAP) Project aimed at developing a defensible, science-based quantitative

14 methodology for determining risk profiles at $\mathrm{CO}_{2}$ storage sites. As part of this effort, scientists from

15 Lawrence Berkeley National Laboratory (LBNL), Lawrence Livermore National Laboratory (LLNL), Los

16 Alamos National Laboratory (LANL), Pacific Northwest National Laboratory (PNNL), and the National

17 Energy Technology Laboratory (NETL) are developing reduced-order models (ROMs) to evaluate the

18 potential for aquifer impacts should $\mathrm{CO}_{2}$ or brine leak from deep subsurface storage reservoirs. This

19 methodology uses detailed physics and chemistry simulation results to train more computationally

20 efficient ROMs. These ROMscan be used to help regulators and operators understand the potential sizes

21 and longevity of contaminant plumes that could result from leakage of brine and/or $\mathrm{CO}_{2}$ from a storage reservoir into underground sources of drinking water (USDW) (Carroll et al., 2014).

Hypothetical leakage scenarios have focused on wellbores as the most likely conduits from the storage reservoir to the USDW (Fig. 1). To compare potential groundwater impacts, simulation results are used to calculate the volume of aquifer exceeding some groundwater quality threshold concentration. Initially, threshold values were based on the U.S. Environmental Protection Agency (EPA) national primary and secondary drinking water limits. However, feedback received from the NRAP Stakeholder Group indicated that additional threshold values were needed that could differentiate areas of no degradation (i.e. no impact) from those areas that reflect some degree of change from background groundwater quality

31 levels suggesting potential impacts. Experimental and numerical simulation results (Wang et al., 2015;

32 Lawter et al., 2015; Bacon et al., 2015; and Zheng et al., 2015) indicate that although $\mathrm{CO}_{2}$ and brine

33 leakage may cause decreases in $\mathrm{pH}$ and increases in TDS concentrations beyond regulatory limits in the 

degrade groundwater quality.

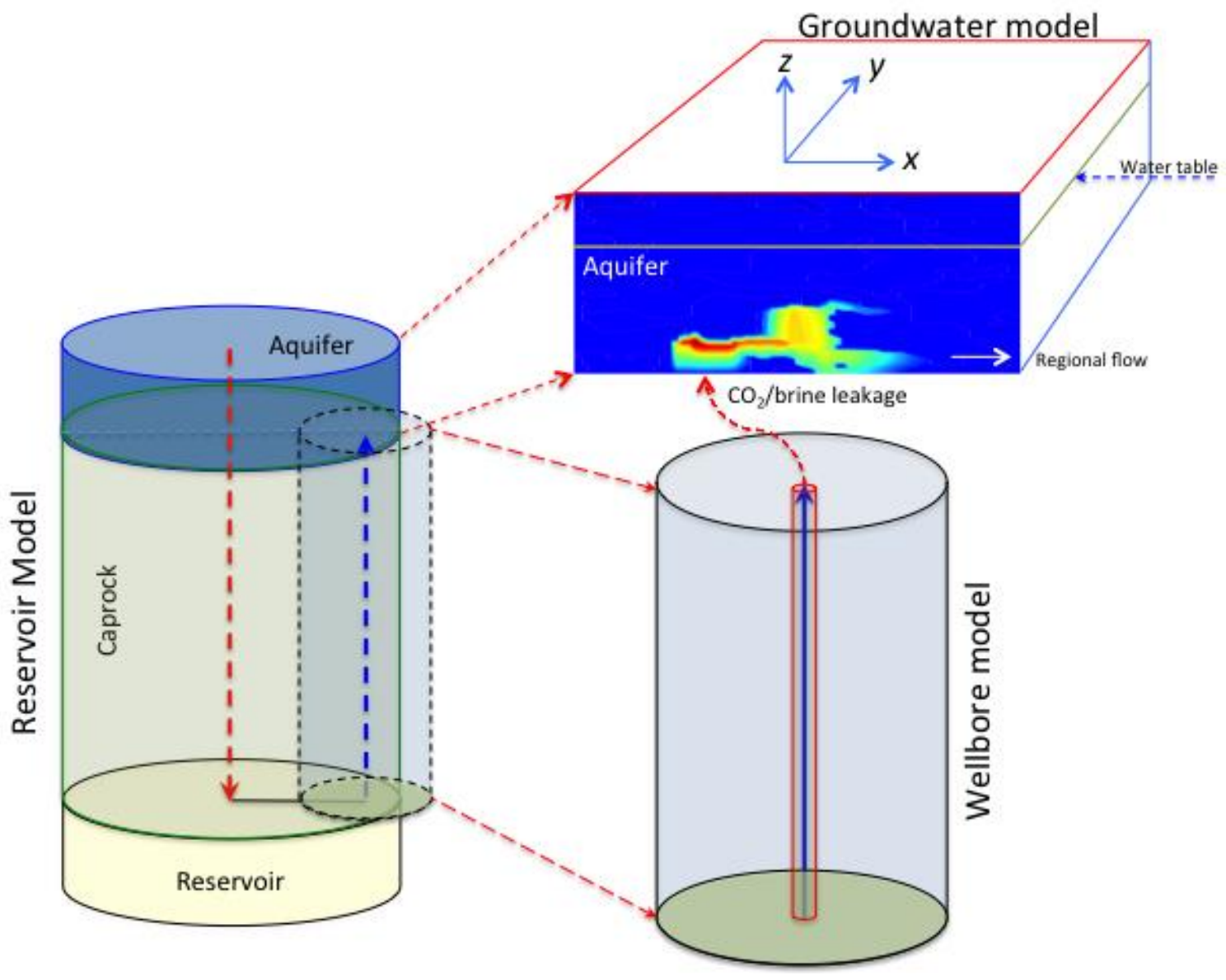

Fig. 1. Conceptual model for simulating potential impacts to an underground source of drinking water (USDW) due to leakage of $\mathrm{CO}_{2}$ and/or brine from a carbon sequestration reservoir (from Carroll et al., 2014)

In this study, we examined various methodologies for determining natural background concentrations and statistical protocols for determining threshold values that would indicate a significant change from the background concentrations. We evaluated the statistical variability of background groundwater concentrations in underground sources of drinking water (USDW) for two classes of USDWs - an unconfined fractured carbonate aquifer based on the Edwards Aquifer in Texas, and a confined alluvium aquifer based on the High Plains Aquifer in Kansas (Carroll et al., 2014). Of particular interest were the constituents $\mathrm{As}, \mathrm{Ba}, \mathrm{Cd}, \mathrm{Cr}, \mathrm{Fe}, \mathrm{Mn}, \mathrm{Pb}, \mathrm{pH}$, TDS, and selected organic elements (benzene, ethylbenzene, naphthalene, toluene, m- \& p-xylene, o-xylene, and phenol). Using these case studies, we evaluated various statistical approaches and converged on a proposed methodology for determining site-specific threshold values that could be used to quantify simulated changes in groundwater chemistry due to $\mathrm{CO}_{2}$ or 
brine leakage from geologic carbon sequestration reservoirs. Our approach generally follows the

2 "interwell" approach recommended for determining background groundwater concentrations (EPA,

3 2009), and using tolerance limits to define threshold values (TVs) representing a significant change over

4 background. There are, however, a number of issues that need to be addressed, including: the potential

5 for these threshold values to actually exceed regulatory limits; the treatment outliers; and the availability

6 of sufficient data to provide reliable statistical results.

\section{$\begin{array}{lll}7 & 2 & \text { Background }\end{array}$}

9 Although not specifically required by the EPA (unlike surface water under the Clean Water Act), the 10 majority of States have established some form of ground-water anti-degradation (or non-degradation)

11 requirements. As a general rule these anti-pollution requirements (not cleanup requirements) are designed 12 to prevent degradation of ground water (e.g. reduced quality from background conditions), by prohibiting 13 or limiting discharges that potentially degrade the ground water; or by requiring maintenance of the 14 ground-water quality consistent with current uses. Often these nondegradation limits are set at definite 15 concentrations (trigger/threshold levels) or at a percentage of the lowest applicable water-quality standard 16 to be measured at the end of a mixing/dilution zone ${ }^{1}$.

Background groundwater concentrations are generally considered to be naturally occurring concentrations that are indicative of minimal influence by human (anthropogenic) sources (USGS - Water Basics Glossary). This is similar to the definition of "Natural Background Levels" used by the Groundwater Daughter Directive (GWDD) adopted by the European Union (EU). Where both natural (geogenic) and anthropogenic sources have contributed to chemical concentrations in the groundwater, the use of the term "baseline concentrations" might be a more appropriate term. The Resource Conservation and Recovery Act (RCRA) uses groundwater concentrations from wells upgradient of a treatment, storage or disposal (TSD) facility to define a local background against which one could compare downgradient concentrations to assess potential impacts from the TSD facility (EPA, 2009).

The EU GWDD uses the term "threshold value" to represent a groundwater quality standard that is based on interactions with aquatic and terrestrial ecosystems, interference with legitimate uses or functions of groundwater, and hydrogeological characteristics including background levels. Groundwater monitoring results that, at a representative monitoring point, exceed the threshold value indicate a risk of failing to

\footnotetext{
${ }^{1}$ Montana Water Quality Information, Nondegradation Determinations \& Mixing Zones. Available at http://deq.mt.gov/wqinfo/nondeg/default.mcpx; accessed 2014-09-09.
} 
achieve good groundwater chemical status (GWDD, 2006). While the GWDD does not provide a formal methodology for establishing natural background levels (NBLs) or threshold values (TVs), it does provide guidelines. BRIDGE (2006) presents a common implementation strategy for the EU, using a tiered methodology based on a choice of different standards depending on whether the receptor is a dependent ecosystem or the groundwater itself (Preziosi et al., 2010). In any case, the BRIDGE methodology uses background levels as the starting point for the definition of TVs for naturally occurring constituents. Excluding samples influenced by human activities, or exceeding $10 \%$ ion balance, the value corresponding to the 90th or 97.7th percentile (depending on the quality and quantity of available data) of the residual data set is considered representative of the NBL, and all values exceeding that level should be ascribed to anthropogenic sources (Preziosi et al., 2010). Others (e.g. Wendland et al., 2008) have developed TVs relative to both the NBLs and a "not acceptable reference value" (e.g., MCL), such that the TVs are higher than the NBLs but lower than the MCLs.

\section{Methods}

Our approach was to define threshold values that would represent a statistically significant change over background or baseline concentrations. This is similar to approaches used under RCRA and the Groundwater Daughter Directive (GWDD) adopted by the European Union (EU). This required that we first define the background concentrations and then define a threshold over which there would be some statistical certainty that the groundwater would be degraded from its background water quality.

Section 7.5 of the EPA's Unified Guidance for Statistical Analysis of Groundwater Monitoring Data at RCRA Facilities (EPA, 2009), suggests that a reasonable statistic for single-sample testing against a fixed groundwater protection standard (GWPS) or TV based on background/baseline would be a background/baseline upper tolerance limit with $95 \%$ confidence and 95\% coverage (Fig. 2). We elected to base our approach for establishing no-impact TVs on the tolerance limit methodology, as it provides a good approximation of the upper limit of the background concentrations, which can be used as a reasonable threshold for identification of significant change to the aquifer. The TV determined using this approach can be interpreted as being an approximation to the upper 95th percentile of the background/baseline distribution. It is designed to be a reasonable maximum on the likely range of background/baseline concentrations. The upper tolerance limit can be calculated as follows:

$$
T L=\bar{x}+\kappa(n, \gamma, 1-\alpha) \cdot s
$$


1 where TL is the tolerance limit, $\bar{x}$ is the mean, $s$ is the standard deviation, and $\kappa(n, \gamma, 1-\alpha)$ is the one-sided

2 tolerance factor for a sample size of $n$, coverage coefficient of $\gamma$, and confidence level of 1- $\alpha$ (EPA,

3 2009). Note that the tolerance limit is different from the more well-known confidence limit around the

4 mean (Fig. 2). Instead, the threshold is expected to contain $95 \%$ of the distribution of all possible

5 measurements in a population with a confidence probability of 95\% (Fig. 2).

6

7 In previous work (Last et al., 2013), we used both parametric and nonparametric tolerance limits to set

8 TVs. However, Gibbons (1994) suggests that nonparametric tolerance limits should only be used if more

9 than 59 data are available for the calculation. In the case studies presented here, the maximum number of 10 data is 30 , so we have used parametric tolerance limits throughout.

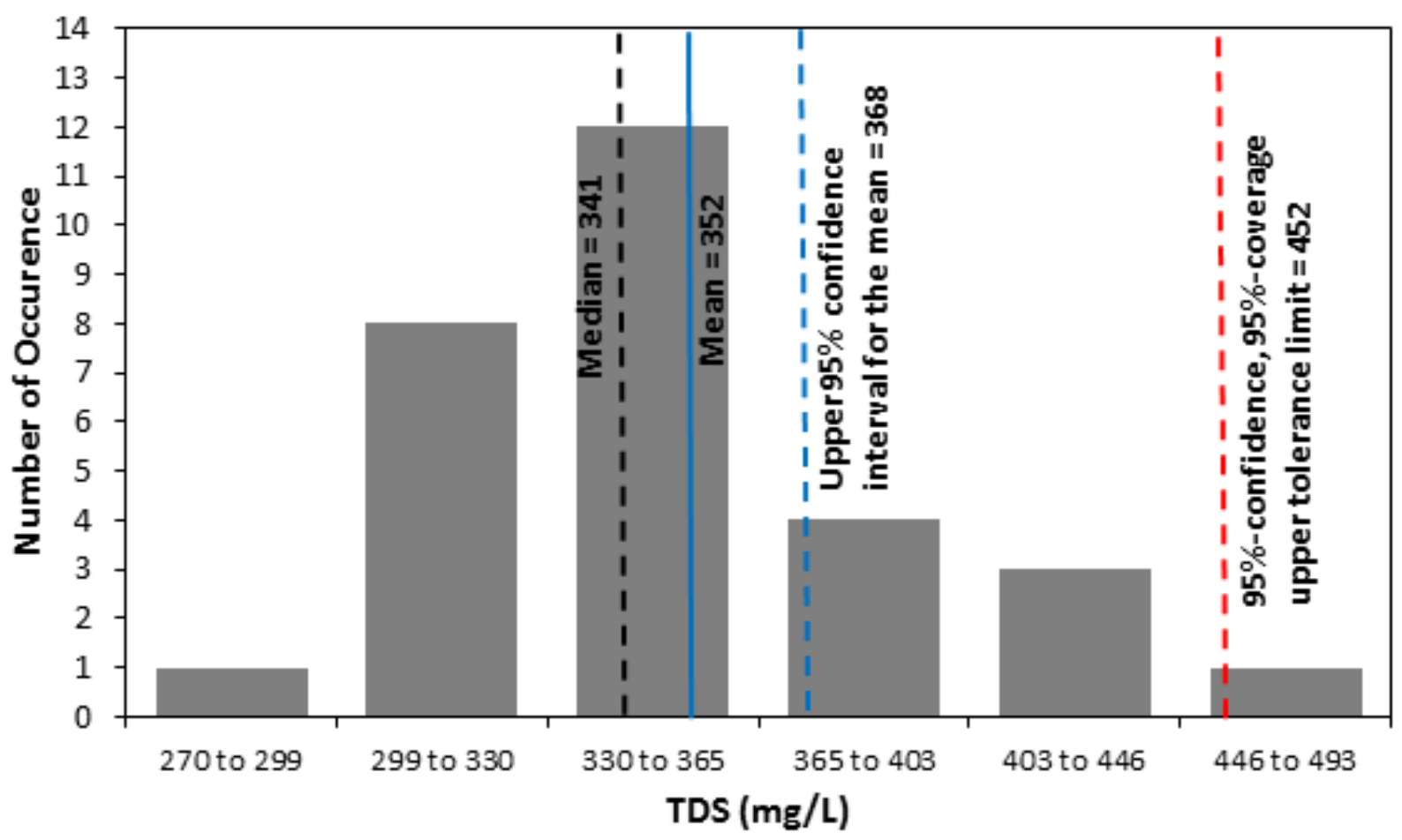

13

14

15

Fig. 2. Example of a background upper tolerance limit that approximates the upper $95^{\text {th }}$ percentile of a background distribution of a contaminant of interest.

Standard procedures (EPA, 2009) were used to process the geochemical data before developing the initial values and thresholds. Outliers were identified using upper boundaries equal to the upper quartile (i.e., 75th percentile) of the data plus $1.5 *$ the interquartile range (IQR), where the IQR is the difference between the upper and lower quartiles of the data (Tukey, 1977). The lower boundary was identified as 
1 the lower quartile (i.e., 25th percentile) minus $1.5 *$ IQR. Outliers were removed from the data if they

2 exceeded the upper bound or were lower than the lower bound.

4 Where variables were strongly skewed, as shown by examination of histograms and normal probability

5 plots, logarithmic transforms of the data were used to identify outliers and calculate initial values and no-

6 impact thresholds. Where a substantial number of nondetects (values noted as less than the detection

7 limit) were present in the data, we used the R package "NADA" (Lee, 2012) to calculate statistics that

8 accounted for the presence of nondetects in the data, following the methodology published by (Helsel,

9 2012). Note that following the EPA Unified Guidance (EPA, 2009), data reported with "E" or "J" data

10 qualifiers that were reported with an estimated concentration were treated as valid measurements for

11 statistical purposes.

13 To explore the statistical approaches for determining threshold values proposed here, we present two case

14 studies, using data used by Bacon (2013) and Bianchi et al. (2014). Bacon (2013) used data for the

15 shallow/urban unconfined portion of the San Antonio Segment of the Edwards Aquifer, taken from

16 appendices in Musgrove et al. (2010) that included National Water Quality Assessment (NAWQA) data

17 collected from 1996 through 2006. Bianchi et al. (2014) used data for the High Plains Aquifer collected

18 in 1999 and 2010 and downloaded directly from the U.S. Geological Survey (USGS) NAWQA data

19 warehouse website ${ }^{2}$.

\section{Shallow/urban unconfined portion of the San Antonio segment of the Edwards Aquifer, Texas}

The San Antonio Segment of the Edwards Aquifer in central Texas is a productive karst aquifer developed in Cretaceous-age limestone and dolomite rocks that are extensively faulted and fractured (Musgrove et al., 2010). The San Antonio segment of the Edwards Aquifer lies in a narrow band along the Balcones fault zone (Musgrove et al., 2010). Recharge to the Edwards Aquifer occurs primarily (60-90\%) from losing streams, with the remaining recharge from direct infiltration and leakage from the underlying Trinity Aquifer.

The San Antonio region is prone to climatic and hydrologic extremes with high short-term rainfall and rapid runoff events, and droughts lasting from many months to years (Musgrove et al., 2010). Like other karst aquifers, the Edwards Aquifer responds rapidly to changes in hydrologic conditions, with

\footnotetext{
${ }^{2}$ NAWQA data warehouse website at http://co.water.usgs.gov/nawqa/hpgw/datarep/cos/COS.html; accessed 2014-09-09.
} 
1 accompanying changes in water levels, spring discharge rates, and water quality (Musgrove et al., 2010).

2 Musgrove et al. (2010) also reported that there are a number of volcanic and intrusive igneous rocks that

3 locally cross-cut the aquifer and may affect groundwater chemistry. The NAWQA Program provides an

4 extensive data set of groundwater geochemistry and water quality for the San Antonio segment of the

5 Edwards Aquifer. These data come from both wells and springs, including wells completed in the

6 shallow, unconfined, and urbanized part of the aquifer near San Antonio. Musgrove et al. (2010) found

7 that the shallow/urban unconfined part of the Edwards Aquifer is the portion of the aquifer most affected

8 by anthropogenic contaminants, as demonstrated by routine or frequent detection of organic contaminants

9 such as pesticides atrazine, its degradate deethylatrazine, and simazine; the drinking-water disinfection

10 byproduct chloroform; and the solvent tetrachloroethene.

\section{$11 \quad 4.1 \quad \underline{\text { Selection of groundwater quality data }}$}

12

13 Bacon (2013) describes the development of a two-dimensional, heterogeneous model of groundwater

14 flow and reactive transport in the Edwards Aquifer. The model domain covered an 8-km $\times 5-\mathrm{km}$ area

15 based on the shallow, unconfined portion of the Edwards Aquifer near San Antonio, Texas. There were

1630 well locations in the shallow, unconfined Edwards aquifer that provided the data used for the study.

17 Bacon (2013) examined water samples from this portion of the aquifer (Musgrove et al., 2010) and found

18 them to all be calcium bicarbonate-type waters. Using this same data set, we found that the 30 wells for

19 the shallow, urban unconfined aquifer (Fig. 3) were all within about $28 \mathrm{~km}$ (17 mi) of each other.

21 A brief analysis of the proportion of nondetects revealed that arsenic, cadmium, and lead were all below

22 detection for almost all samples collected prior to 2001 (due in part to higher detection limits of the

23 instruments used at that time). Therefore, only the data that were collected during a sampling campaign

24 in 2006 that sampled all 30 wells (Musgrove et al., 2010) were used for analysis of metals concentrations.

25 Although most wells were only sampled once in 2006, several were sampled twice; for those wells, the

26 average of the two concentrations was used. Statistics for $\mathrm{pH}$ and TDS found no statistically significant

27 difference between data from different time periods, thus, the full data set could be used. However, for

28 consistency, we used the 2006 data for analysis of $\mathrm{pH}$ and TDS. The vast majority of organic

29 concentration data were nondetects, with the largest number of "detects" for toluene, where 7 out of the

30 90-sample data set yielded an estimated value (i.e. J-values). 


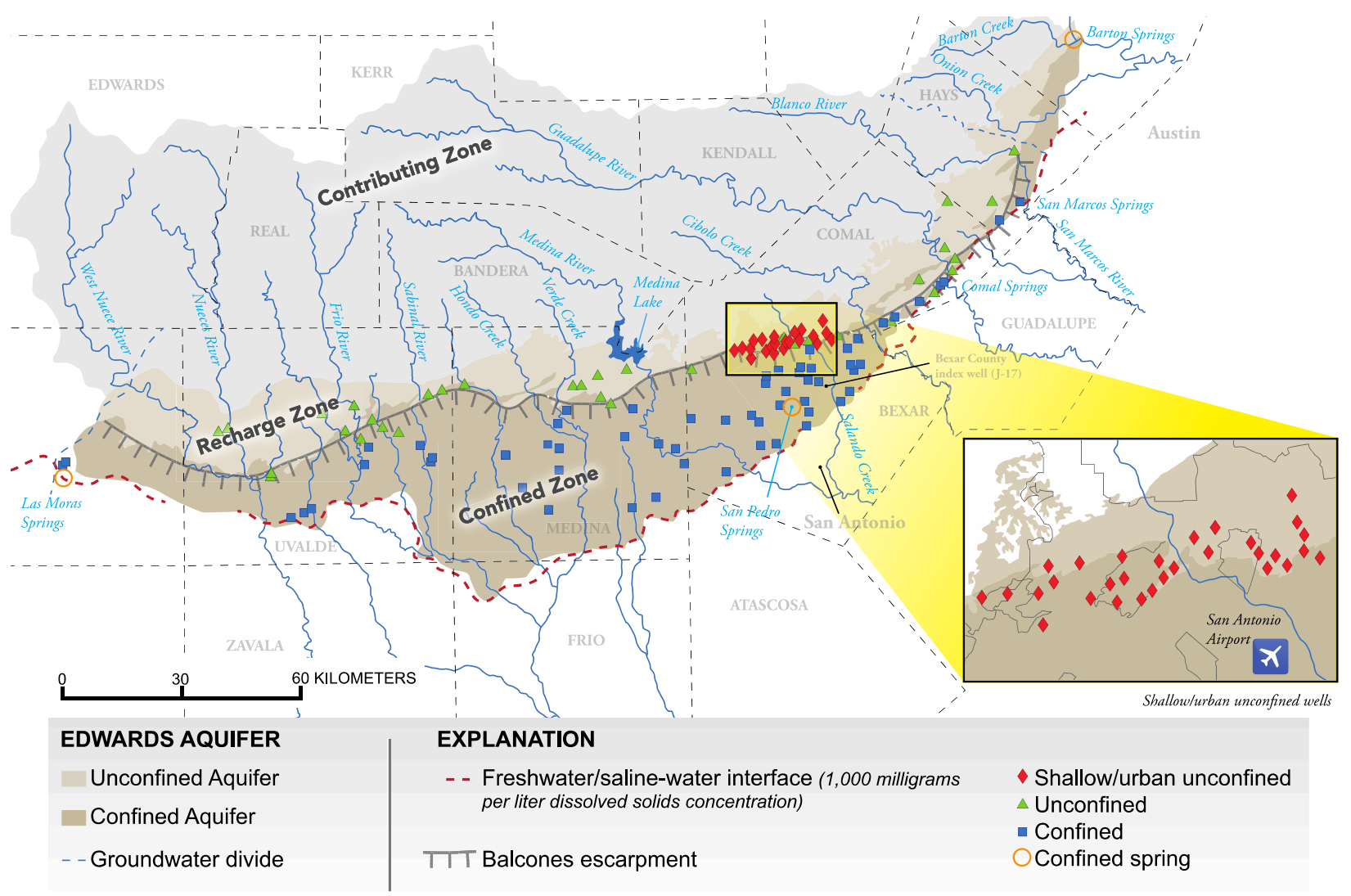

Fig. 3. Location of shallow/urban unconfined wells for the Edwards Aquifer (taken from Musgrove et al., 2010).

\subsection{Determination of initial conditions and threshold values}

Bacon (2013) used single values to initialize a model run, which assumes that the data distributions are somewhat stationary. Examination of Fig. 4 suggests that assumption may not be supported, so future work may look at the influence of spatially variable initial distributions on the variability of the resulting ROM. We used the medians of the selected data for each variable as initial values for the ROMs (Table 1), because they were less influenced by the skewed nature of the distributions. In some cases, the initial

11 values and threshold values reported here are updated versions of those reported in Carroll et al., 2014.

\section{$12 \quad 4.2 .1 \quad \underline{\text { Arsenic }}$}

13 For the As concentrations, three outliers were identified using logarithmically transformed concentration

14 data. Fig. 4a shows contours of the As concentrations based on the concentrations for all 30 observations

15 from 2006. The 27 observations that were used as the selected dataset are circled in Fig. 4a, which shows 16 three outliers exceeding the upper outlier criterion of $0.45 \mu \mathrm{g} / \mathrm{L}$. The initial value selected for modeling 
was the median of the data, $0.29 \mu \mathrm{g} / \mathrm{L}$ (Table 1). The no-impact TV for the 27 values in the selected As

2 data set was $0.46 \mu \mathrm{g} / \mathrm{L}$, which is more than an order of magnitude less than the regulatory value for As

3 (Table 1).

4
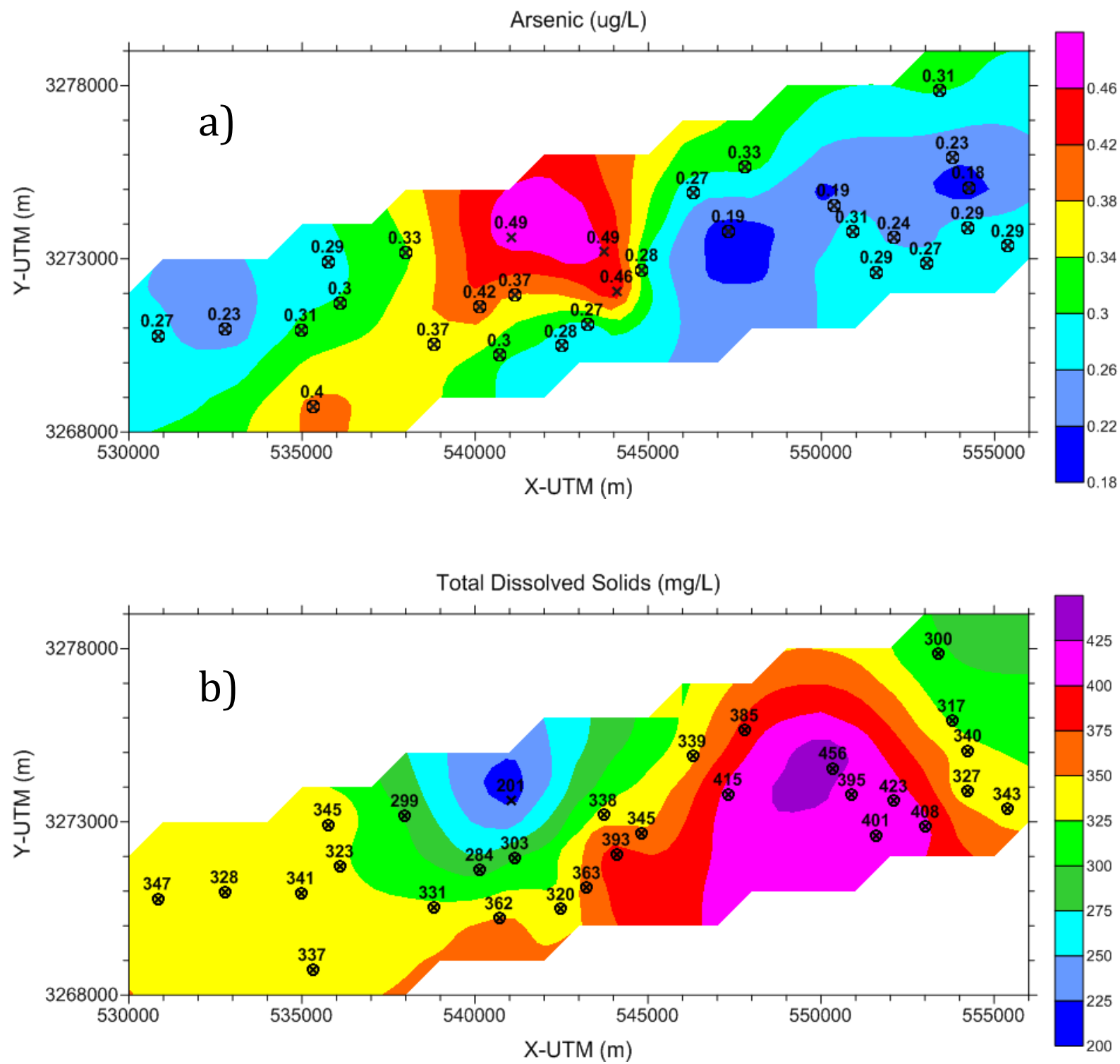

Fig. 4. Maps showing data distribution and contours of a) As, and b) TDS for the Edwards Aquifer case study. Circled wells are those used in calculating the no-impact thresholds. Refer to the inset in Figure 3 for locations.

\section{$10 \quad 4.2 .2 \quad \underline{B a r i u m}$}

11 Two outliers were identified for barium in the 2006 concentration data, using a logarithmic transform of

12 the data. Closer examination of those outliers showed that the concentrations of barium at one of the 
1 wells, the AY-68-28-314, show a generally increasing trend from 1998 through 2006 (Fig. 5). This

2 indicates that the outlier present in 2006 for that well is not a result of an isolated typographic or

3 laboratory error, and probably results from anthropogenic input. The initial barium concentration value

4 selected for the modeling was the median value of $38 \mu \mathrm{g} / \mathrm{L}$ (Table 1). The TV for barium was based on a

$5 \log$ transform of the 28 data remaining after removal of the two outliers, with a value of $54 \mu \mathrm{g} / \mathrm{L}$ (Table

6 1), which is almost two orders of magnitude lower than the regulatory limit of $2,000 \mu \mathrm{g} / \mathrm{L}$.

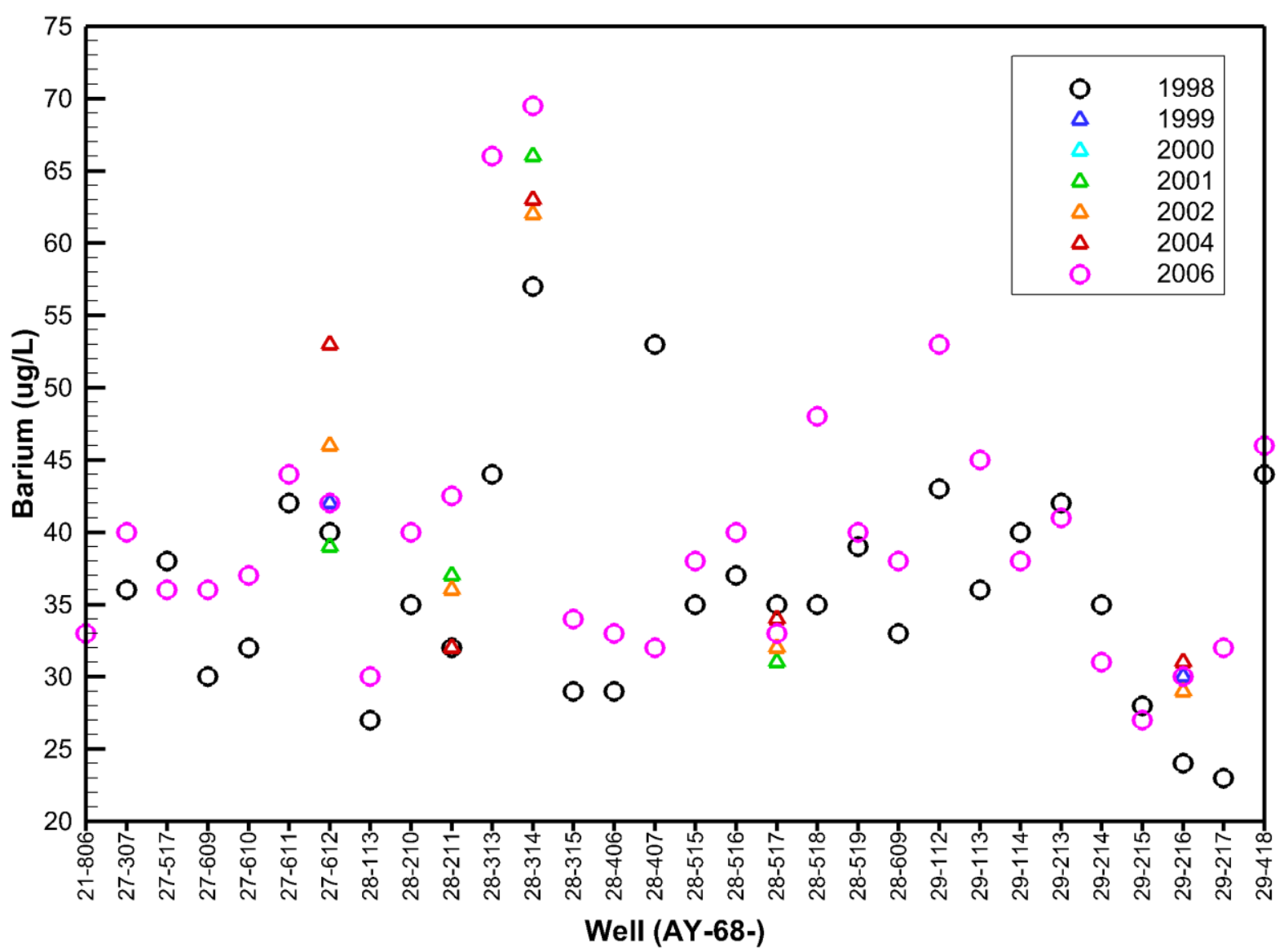

7

Fig. 5 Distribution of measured Barium values over time for the Edwards Aquifer case study.

$10 \quad 4.2 .3 \quad \underline{\text { Cadmium }}$

11 No data above the detection limit were available for cadmium, thus, the upper tolerance limit was set

12 equal to the detection limit reported for the data of $0.04 \mu \mathrm{g} / \mathrm{L}$, and an initial concentration of 0 was used

13 (Table 1). A cadmium concentration value above the detection limit would therefore indicate the

14 presence of contamination during a groundwater-modeling run. 
2 Lead concentrations for 9 of the 30 wells were below detection in the Fall 2006 sampling, or 30 percent of

3 the values (Fig. 6). This exceeds the 10\%-15\% threshold for simple substitution suggested in the EPA

4 Unified Guidance (2009), so the "ros" function in the NADA package (Lee, 2012) was used to calculate

5 censored statistics for the log-transformed lead data. The "ros" function calculates regression order

6 statistics (Lee and Helsel 2005) to more properly account for nondetects in calculating statistical

7 summaries for water quality data that include multiple detection limits. . No outliers were found in the

8 analysis and the censored statistics reflect all samples, so Table 1 indicates 30 samples for lead. Censored

9 statistics for lead indicated a median of $0.07 \mu \mathrm{g} / \mathrm{L}$, which was suggested for the initial value, and a TV of

$10 \quad 0.14 \mu \mathrm{g} / \mathrm{L}$, which is an order of magnitude lower than the regulatory limit of $15 \mu \mathrm{g} / \mathrm{L}$ (Table 1 ).

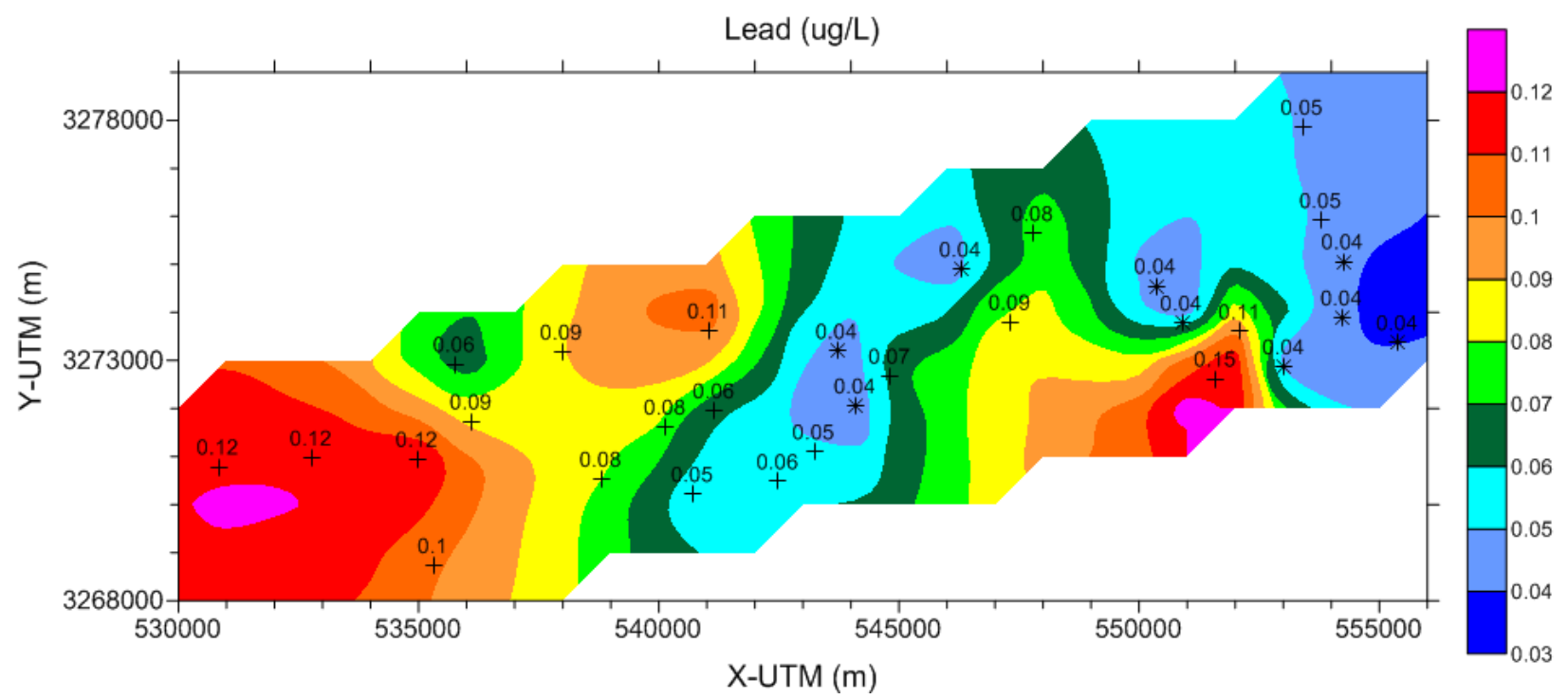

Fig. 6 Contours of $\mathrm{Pb}$ concentrations for the Edwards Aquifer. Nondetects (shown with an asterisk) were replaced by half the nondetect value for contouring. Refer to the inset in Figure 3 for locations. Because $30 \%$ of the Pb data were nondetects, censored statistics were used in calculation of the initial value and TV.

\section{$15 \quad 4.2 .5 \quad \underline{\mathrm{pH}}$}

16 The TV for $\mathrm{pH}$ was calculated based on a lower $95 \%$ coverage, $95 \%$ probability tolerance limit rather

17 than the upper tolerance limit used for the other variables. The lower tolerance limit was chosen for $\mathrm{pH}$

18 because the escape of sequestered $\mathrm{CO}_{2}$ would typically result in a decrease in $\mathrm{pH}$ in overlying aquifers

19 (Carroll et al., 2014). Examination of the $\mathrm{pH}$ data led to identification of several outliers. The

20 recommended initial value, based on the median of the 27 selected data was 6.9, with a TV of 6.7.

\section{$21 \quad 4.2 .6 \quad \underline{\text { Total Dissolved Solids (TDS) }}$}

22 Examination of log-transformed TDS data identified one low outlier, below the lower outlier criterion of

$23256 \mathrm{mg} / \mathrm{L}$. The distribution of the 29 circled data used in setting the threshold is shown in Fig. 4b. For 
1 TDS, TV calculated from the 29 selected data of $450 \mu \mathrm{g} / \mathrm{L}$ was $90 \%$ of the regulatory limit, much higher

2 relative to the regulatory limit than most of the other variables examined.

\section{$3 \quad 4.2 .7 \quad$ Selected Organic Compounds}

4 The vast majority of organic concentration data for benzene, ethylbenzene, naphthalene, toluene, m- \& p-

5 xylene, o-xylene, and phenol were nondetects. The largest number of "detects" were for toluene, where 7

6 out of the 90-sample data set yielded an estimated value (i.e. J-values), and those estimated values were

7 all less than the stated detection limit for the rest of the samples. Thus, the initial values were defined at

8 zero, and TV for the organic compounds were set at the most recent (i.e. 2006) detection limit.

Table 1. Initial values and no-impact thresholds for Edwards Aquifer case study.

\begin{tabular}{|c|c|c|c|c|c|}
\hline Constituent & Number of Samples $^{(t)}$ & Initial Value $^{(a)}$ & No-Impact Threshold $^{\text {(a) }}$ & Regulatory Limit & Units \\
\hline Arsenic & 27 & 0.29 & 0.46 & 10 & $\mu \mathrm{g} / \mathrm{L}$ \\
\hline Barium & 28 & 38 & 54 & 2000 & $\mu \mathrm{g} / \mathrm{L}$ \\
\hline Cadmium $^{(\mathrm{b})}$ & ND & 0 & 0.04 & 5 & $\mu \mathrm{g} / \mathrm{L}$ \\
\hline Lead $^{(\mathrm{g})}$ & 30 & 0.07 & 0.14 & 15 & $\mu \mathrm{g} / \mathrm{L}$ \\
\hline $\mathrm{pH}$ & 27 & 6.9 & 6.7 & 6.5 & -- \\
\hline Total Dissolved & 29 & 340 & 450 & 500 & $\mathrm{mg} / \mathrm{L}$ \\
\hline \multicolumn{6}{|l|}{ Solids } \\
\hline Benzene $^{(b)}$ & ND & 0 & 0.016 & 5 & $\mu \mathrm{g} / \mathrm{L}$ \\
\hline ethylbenzene $^{(b)}$ & ND & 0 & 0.02 & 700 & $\mu \mathrm{g} / \mathrm{L}$ \\
\hline naphtalene $^{(\mathrm{b})}$ & ND & 0 & 0.4 & UR & $\mu \mathrm{g} / \mathrm{L}$ \\
\hline toluene & ND & 0 & 0.018 & 1,000 & $\mu \mathrm{g} / \mathrm{L}$ \\
\hline m- \& p-xylene ${ }^{(\mathrm{b})(\mathrm{c})}$ & ND & 0 & 0.08 & 10,000 & $\mu \mathrm{g} / \mathrm{L}$ \\
\hline o-xylene ${ }^{(b)(c)}$ & ND & 0 & 0.04 & 10,000 & $\mu \mathrm{g} / \mathrm{L}$ \\
\hline phenol $^{(\mathrm{b})(\mathrm{d})(\mathrm{e})}$ & ND & 0 & 0.005 & 10,000 & $\mu \mathrm{g} / \mathrm{L}$ \\
\hline \multicolumn{6}{|c|}{${ }^{(a)}$ Rounded to two significant digits } \\
\hline \multicolumn{6}{|c|}{ (b) all values below detection limits. } \\
\hline \multicolumn{6}{|l|}{ (c) Xylenes (total) } \\
\hline \multicolumn{6}{|c|}{ (d) as 4-Chloro-2-methylphenol } \\
\hline \multicolumn{6}{|c|}{ (e) Recommended Water Quality Criteria for Human Health, consumption of Water + Organism (74 FR 27535); } \\
\hline \multicolumn{6}{|c|}{ http://water.epa.gov/scitech/swguidance/standards/criteria/current/index.cfm\#hhtable } \\
\hline \multicolumn{6}{|c|}{ (f) after elimnation of outliners } \\
\hline \multicolumn{6}{|c|}{ (g) 9 values were below the detection limit } \\
\hline \multicolumn{6}{|c|}{$\mathrm{ND}=$ Not detected - all values below detection limit. } \\
\hline $\mathrm{UR}=$ Unregulated & 2003 |EPA-815-R-03-1 & & & & \\
\hline
\end{tabular}

\section{Central High Plains Aquifer}

12

13 The High Plains Aquifer consists of near-surface sedimentary deposits of Tertiary and Quaternary age

14 that are interconnected to form a regional unconfined aquifer system (McMahon et al., 2007). Tertiary 
1 sediments of the Ogallala Formation form a large part of the High Plains Aquifer. These sediments were

2 deposited by aggrading streams that deposited a heterogeneous sequence of clay, silt, sand, and gravel

3 filling buried valleys eroded into pre-Ogallala rocks. Locally cemented zones consisting of calcium

4 carbonate (caliche), and sometimes silica, occur near the top of the formation, forming escarpments that

5 mark the boundary of the aquifer system in the Central High Plains (McMahon et al., 2007). Bedrock

6 units of Permian to Tertiary age underlie the High Plains Aquifer. These less permeable bedrock

7 sediments locally act as a source of groundwater; in some cases, large concentrations of dissolved solids,

8 particularly in the Permian age sediments, could affect the quality of water in the High Plains Aquifer

9 (McMahon et al., 2007).

11 Recharge to the High Plains Aquifer occurs by infiltration of irrigation water, areally diffuse infiltration

12 from precipitation, focused infiltration of storm- and irrigation-water runoff, and upward movement of

13 water from underlying aquifers (McMahon et al., 2007). Discharge from the High Plains Aquifer

14 generally occurs via irrigation well pumping, discharge to streams and underlying aquifers, groundwater

15 flow across the eastern boundary of the aquifer, and evapotranspiration (McMahon et al., 2007).

The NAWQA Program provides an extensive data set of groundwater geochemistry and water quality for the High Plains Aquifer. The major-aquifer study data set comes from sampling networks of randomly distributed domestic wells in the major hydrogeologic units (McMahon et al., 2007). Water samples were analyzed for various combinations of field properties, major ions, nutrients, trace elements, pesticides, volatile organic compounds, stable and radioactive isotopes, and dissolved gases. McMahon et al. (2007) found that irrigated cropland was a direct or indirect source of salts, nitrate, and pesticides to the High Plains Aquifer, and that urban land was also a source of those constituents, as well as volatile organic 24 compounds.

\section{$25 \quad 5.1 \quad$ Selection of groundwater quality data}

The Central High Plains Aquifer data set used by Bianchi et al. (2014) included results from both 1999 and 2010. However, only the 2010 results from the 30 major aquifer wells covering the central high plains aquifer were selected for threshold analysis. We further examined the data for outliers using Tukey's criteria (Tukey, 1977). In most cases the examination of outliers was performed for a logarithmic transform of the data to reduce the asymmetry of the data distribution.

These samples cover a large spatial area — several hundred kilometers in extent covering portions of four 
is much different than the situation for the Edwards Aquifer data set. Because of the regional extent of

2 the map and well locations shown in Figure 7, we were not able to use the UTM coordinate system to

3 map the concentration data. We therefore used an Albers-Equal-Area-conic projection in Figures 8 and 9.

4 Note that the red outline of the model location shown in Figure 7 is the same as the small black square

5 shown as the model location in Figures 8 and 9.

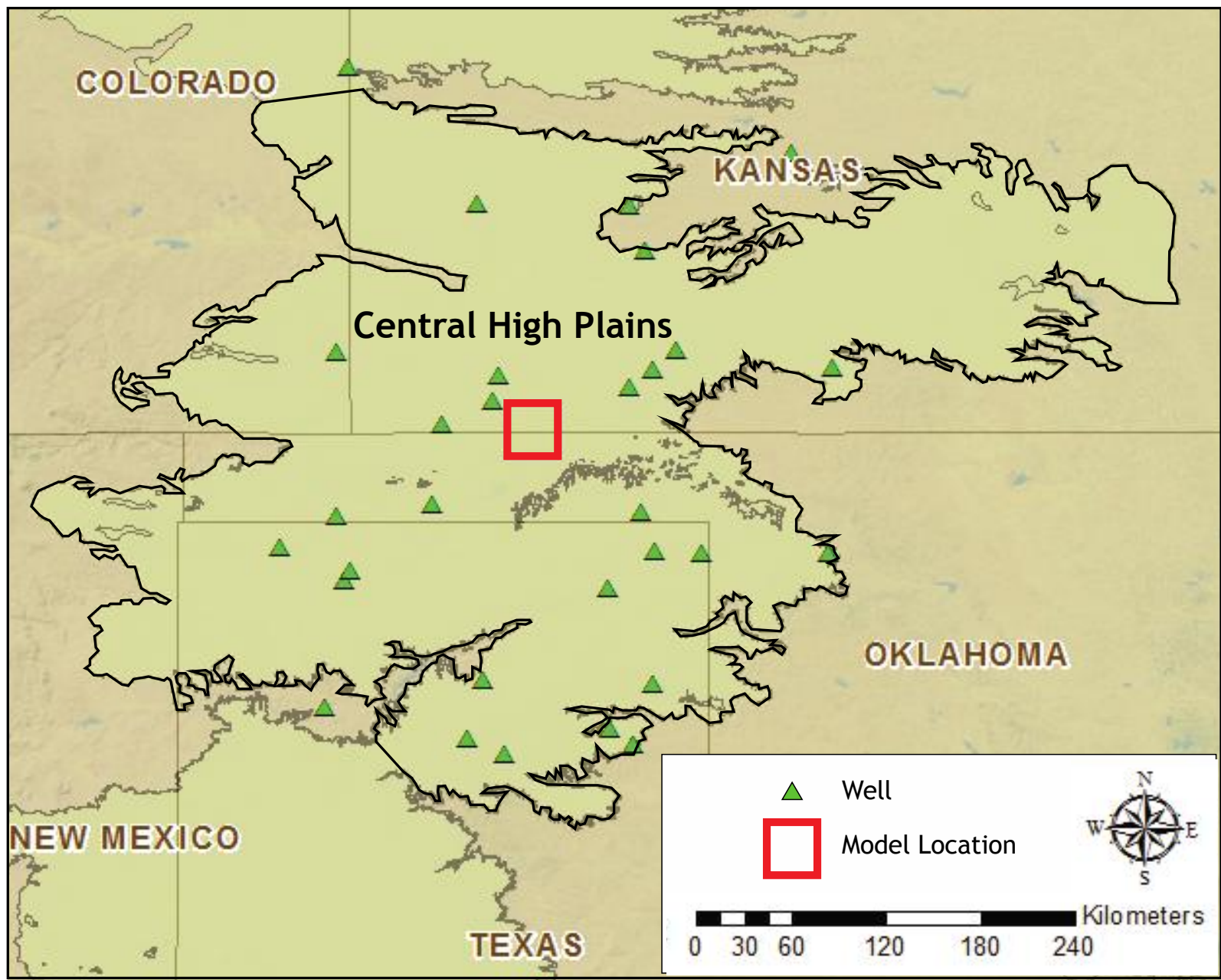

Fig. 7. Locations of major-aquifer study wells for the 2010 NAWQA data set (after McMahon et al., 2007)

\subsection{Determination of initial conditions and threshold values}

10 As with the Edwards modeling, the modeling of the High Plains Aquifer documented by Carroll et al.

11 (2014) used single values to initialize a model run, which assumes that the data distributions are

12 somewhat stationary. We used the medians of the selected data for each variable as initial values for the

13 ROMs (Table 2), because they were less influenced by the skewed nature of the distributions. In some

14 cases, the initial values and threshold values reported here are updated versions of those reported in

15 Carroll et al., 2014. 
Fig. 8. Maps showing data distribution and contours of a) As, and b) TDS for the Central High Plains Aquifer case study. Circled wells are those used in calculating the no-impact thresholds. The black square represents the location of the ROM.
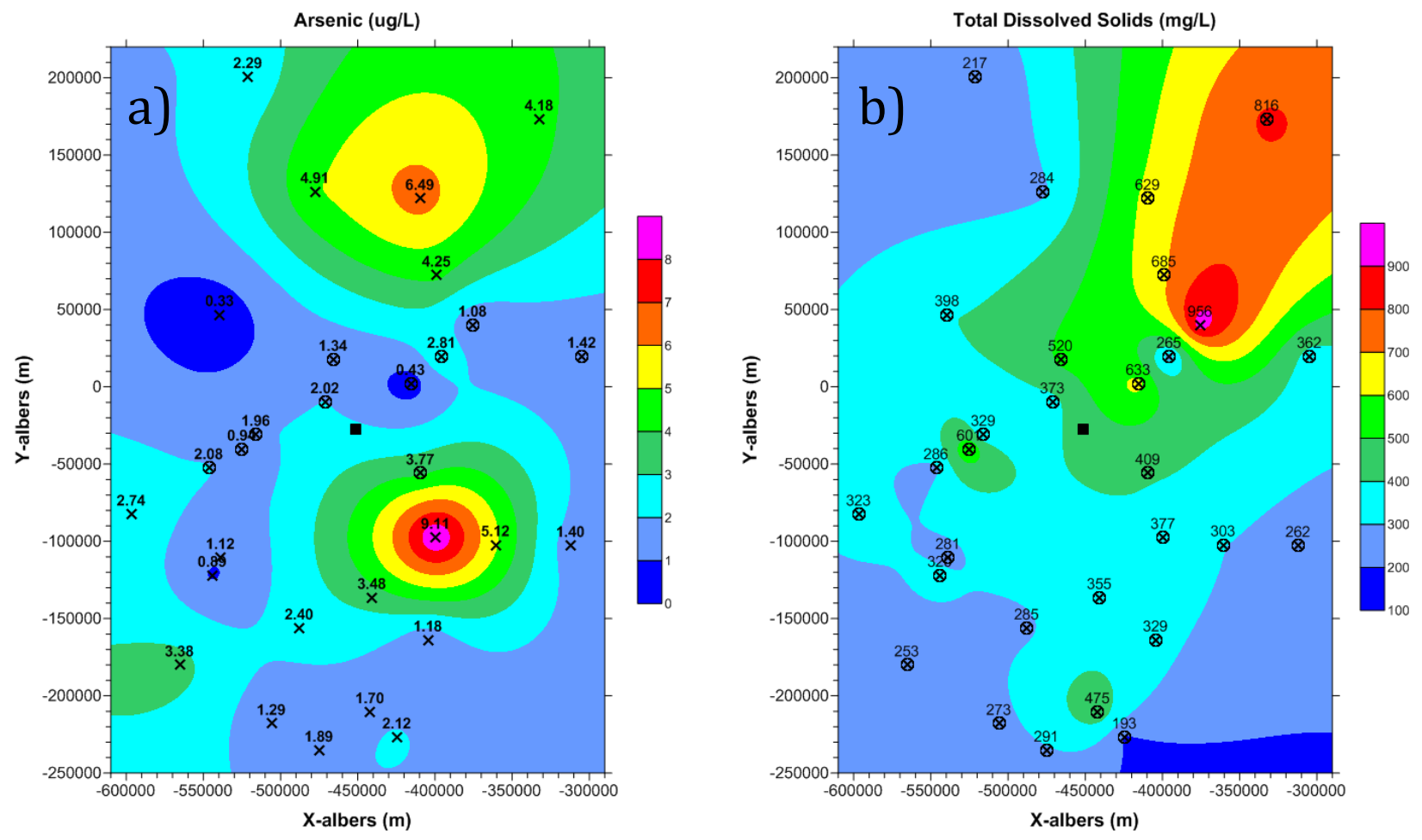

\section{$1 \quad 5.2 .1 \quad \underline{\text { Arsenic }}$}

2 In examining the distribution of the As data for the High Plains Aquifer (Fig. 8a), a band of wells with

3 relatively low values was identified in the center of the map, in the general area of the model location.

4 The As data selected for the study consisted of the 10 values highlighted by circles on the map, in order to

5 reflect the lower concentrations observed closest to the model location.

7 The concentration level identified for the initial value for As for the ROM was the median value of 1.7

$8 \mu \mathrm{g} / \mathrm{L}$ (Table 2). The no-impact threshold limit for As was $9.2 \mu \mathrm{g} / \mathrm{L}$, about $90 \%$ of the regulatory limit.

\section{$11 \quad 5.2 .2 \quad \underline{\text { Barium }}$}

12 As with As, significant spatial heterogeneity was seen for Ba, with an area of low concentrations closest

13 to the model area. Thirteen samples from that area were selected for inclusion in the statistical analysis.

14 No nondetects were present and no outliers were detected. The median value of $43 \mu \mathrm{g} / \mathrm{L}$ was

15 recommended for an initial value, with a TV of $140 \mu \mathrm{g} / \mathrm{L}$. The TV was more than an order of magnitude

16 lower than the regulatory limit of $2,000 \mu \mathrm{g} / \mathrm{L}$. 


\section{$1 \quad 5.2 .3 \quad \underline{\text { Cadmium }}$}

2 An area with generally higher concentrations was present in the center of the study area, and based on that

3 characterization, 22 samples were selected. There were two nondetects present in the selected data set,

4 but that was only $9 \%$ of the selected data, so we substituted half the non-detect value for nondetects

5 following EPA Unified Guidance (EPA, 2009). Two upper outliers were excluded from the selected data

6 set based on a log transformation of the data. The median value of the selected data set was $0.05 \mu \mathrm{g} / \mathrm{L}$,

7 with an upper TV of $0.24 \mu \mathrm{g} / \mathrm{L}$ that is more than an order of magnitude less than the regulatory limit

8 (Table 2).

$9 \quad 5.2 .4 \quad$ Chromium

10 The chromium data varied spatially, but there was no distinct pattern, so all 30 samples from 2010 were

11 selected. Two nondetects were present in the data, or 7\%, so we substituted half of the non-detect values

12 for those data. No outliers were identified, and the median chromium concentration was $0.97 \mu \mathrm{g} / \mathrm{L}$, and

13 the upper TV was calculated at $7.7 \mu \mathrm{g} / \mathrm{L}$ (Table 2).

\section{$14 \quad 5.2 .5 \quad \underline{\text { Iron }}$}

15 A large amount of spatial variability was present in the iron data, and both very high values and

16 nondetects were close to the modeling area, so all 30 samples were selected. Four outliers were detected

17 based on an upper outlier limit of 19.9, so 26 samples were retained for the statistical analysis. A large

18 proportion of the samples (47\%) were below detection (Fig. 9), so we used censored statistics to account

19 for nondetects. The median of $5.1 \mu \mathrm{g} / \mathrm{L}$ was suggested as an initial value. The TV for the selected data

20 was $14 \mu \mathrm{g} / \mathrm{L}$.

21 


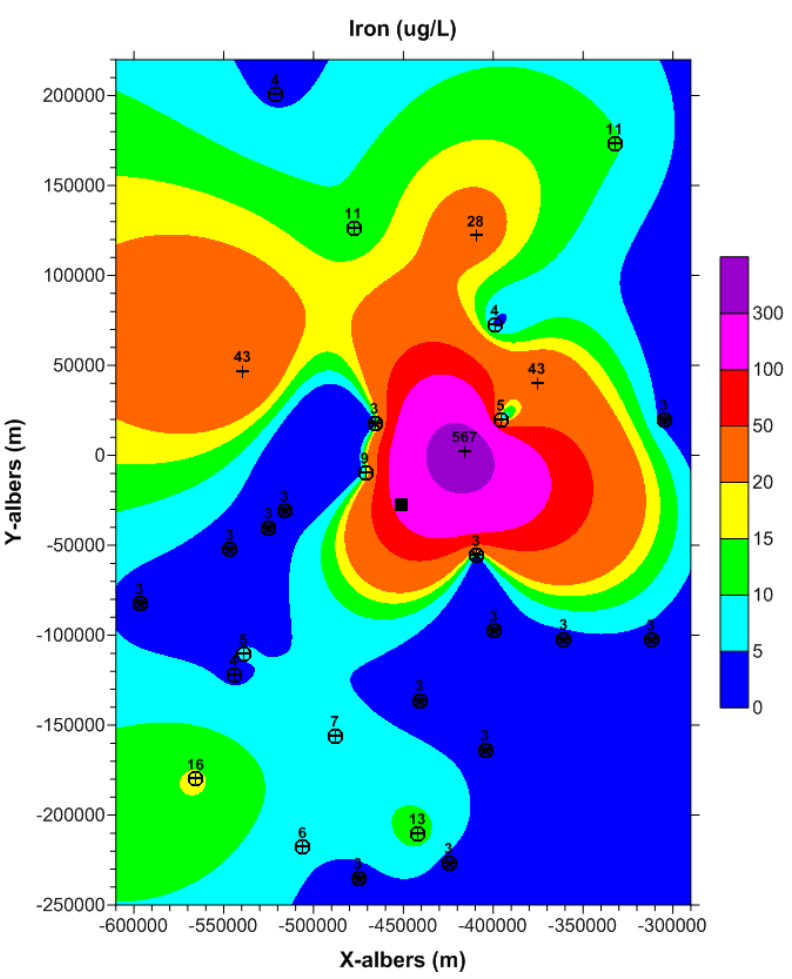

2 Fig. 9. Map of the distribution of Fe in the Central High Plains aquifer. The model location is marked as a solid square, and the data used in analysis are circled. The locations with nondetect values are marked by an asterisk; they were

4 assigned half the non-detect values for contouring the map.

\section{$5 \quad 5.2 .6 \quad \underline{\text { Manganese }}$}

6 All 30 samples from 2010 were selected for analysis. There were 9 values below detection (30\%), so 7 censored statistics were used with log transformed data. Three outliers were detected above the upper 8 outlier limit of $12 \mu \mathrm{g} / \mathrm{L}$, leaving 27 data. The median of the selected Mn data was $0.35 \mu \mathrm{g} / \mathrm{L}$, with a TV 9 of $2.6 \mu \mathrm{g} / \mathrm{L}$.

$10 \quad 5.2 .7 \quad \underline{\text { Lead }}$

11 All 30 samples were selected for analysis. Nondetects were present in the data, with $10 \%$ of the data 12 below detection, so we substituted half the detection limit for those data. No outliers were detected. The 13 median of the lead data was $0.10 \mu \mathrm{g} / \mathrm{L}$, which is suggested as the initial value for modeling. A TV of 0.64 $14 \mu \mathrm{g} / \mathrm{L}$ was determined, which is more than an order of magnitude lower than the regulatory limit of 15 $15 \mu \mathrm{g} / \mathrm{L}$ (Table 2).

\section{$16 \quad 5.2 .8 \quad \underline{\mathrm{pH}}$}

17 All 30 samples were selected for analysis of the $\mathrm{pH}$ data. No log transform was applied because the $\mathrm{pH}$ 18 data are already on log scale. No outliers were detected. The median value of the data was 7.5. The TV 19 used for $\mathrm{pH}$ was the lower $95 \%$ tolerance limit of 6.9 . 


\section{$1 \quad 5.2 .9 \quad \underline{\text { TDS }}$}

2 For the TDS data, although there was an overall trend observed in the data, with values generally

3 increasing to the northeast (Fig. 8b), no clear reason was found to restrict the data to a particular area near

4 the model location as both high and low values were present at nearby locations, so the full data set of 30

5 data points were initially selected. A single outlier was identified using a logarithmic transform of the

6 data that exceeded the upper criterion of $710 \mathrm{mg} / \mathrm{L}$. Of the original 30 data points, 7 exceeded the

7 regulatory limit of $500 \mathrm{mg} / \mathrm{L}$.

8

9 The median value of the TDS data of $330 \mathrm{mg} / \mathrm{L}$ used as the initial value for the Central High Plains

10 Aquifer ROM (Table 2) was slightly less than the value found for the Edwards Aquifer (340 mg/L) case

11 study. However, the much higher variability in the regional data set for the Central High Plains Aquifer

12 led to a higher no-impact threshold of $800 \mathrm{mg} / \mathrm{L}$. This would exceed the regulatory limit of $500 \mathrm{mg} / \mathrm{L}$.

\section{$13 \quad$ 5.2.10 Selected Organic Compounds}

14 The vast majority of organic concentration data were nondetects. Thus, the initial values were defined at 15 zero, and TV were set at the most recent (i.e. 2010) detection limit.

16

17

18

Table 2. Initial values and no-impact thresholds for Central High Plains Aquifer case study.

\begin{tabular}{|c|c|c|c|c|c|}
\hline \multirow{2}{*}{ Constituent } & \multicolumn{5}{|c|}{ No-Impact } \\
\hline & Number of Samples ${ }^{(\mathrm{f})}$ & Initial Value $^{(a)}$ & Threshold $^{(a)}$ & Regulatory Limit & Units \\
\hline Arsenic & 10 & 1.7 & 9.2 & 10 & $\mu \mathrm{g} / \mathrm{L}$ \\
\hline Barium & 13 & 43 & 140 & 2000 & $\mu \mathrm{g} / \mathrm{L}$ \\
\hline Cadmium & 20 & 0.05 & 0.24 & 5 & $\mu \mathrm{g} / \mathrm{L}$ \\
\hline Chromium & 30 & 0.97 & 7.7 & 100 & $\mu \mathrm{g} / \mathrm{L}$ \\
\hline Iron & 26 & 5.1 & 14 & 300 & $\mu \mathrm{g} / \mathrm{L}$ \\
\hline Manganese & 27 & 0.35 & 2.6 & 50 & $\mu \mathrm{g} / \mathrm{L}$ \\
\hline Lead & 30 & 0.1 & 0.64 & 15 & $\mu \mathrm{g} / \mathrm{L}$ \\
\hline $\mathrm{pH}$ & 30 & 7.5 & 6.9 & 6.5 & -- \\
\hline Total Dissolved & 29 & 330 & $800^{*}$ & 500 & $\mathrm{mg} / \mathrm{L}$ \\
\hline \multicolumn{6}{|l|}{ Solids } \\
\hline Benzene $^{(\mathrm{b})}$ & ND & 0 & 0.03 & 5 & $\mu \mathrm{g} / \mathrm{L}$ \\
\hline ethylbenzene $^{(\mathrm{b})}$ & ND & 0 & 0.04 & 700 & $\mu \mathrm{g} / \mathrm{L}$ \\
\hline naphtalene $^{(\mathrm{b})}$ & ND & 0 & 0.2 & UR & $\mu \mathrm{g} / \mathrm{L}$ \\
\hline Toluene & ND & 0 & 0.02 & 1,000 & $\mu \mathrm{g} / \mathrm{L}$ \\
\hline m- \& p-xylene ${ }^{(b)(c)}$ & ND & 0 & 0.08 & 10,000 & $\mu \mathrm{g} / \mathrm{L}$ \\
\hline$o-x y l e n e^{(b)(c)}$ & ND & 0 & 0.03 & 10,000 & $\mu \mathrm{g} / \mathrm{L}$ \\
\hline phenol $^{(\mathrm{b})(\mathrm{d})(\mathrm{e})}$ & ND & 0 & 0.003 & 10,000 & $\mu \mathrm{g} / \mathrm{L}$ \\
\hline
\end{tabular}




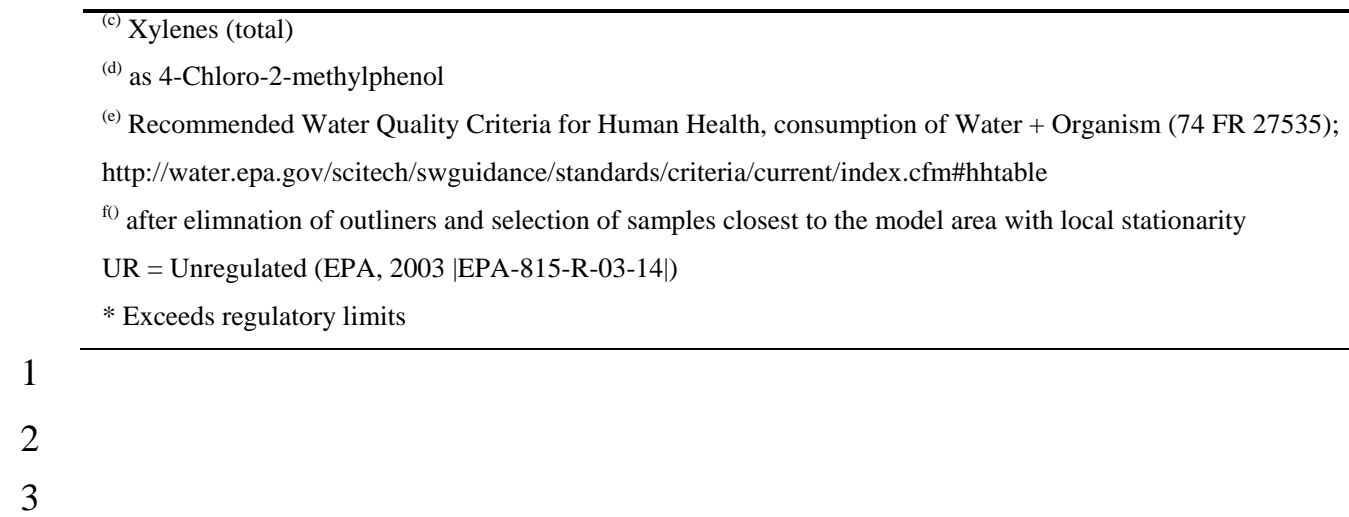

\section{Discussion}

6 NRAP is developing ROMs to evaluate potential impacts to USDWs should $\mathrm{CO}_{2}$ or brine leak from deep 7 subsurface storage reservoirs. To compare potential impacts, simulation results are used to calculate the 8 volumes of aquifer exceeding selected groundwater quality thresholds. In addition to EPA's primary and 9 secondary drinking water limits, additional threshold values were needed that could differentiate areas of 10 no degradation (i.e. no impact) from those areas that reflect some degree of change from background 11 groundwater quality levels.

13 We examined various methodologies for determining natural background concentrations and statistical

14 protocols for determining threshold values that would indicate a significant change from those

15 background concentrations. Our selected approach generally follows the "interwell" approach

16 recommended for determining background groundwater concentrations at sites regulated under the

17 Resource Conservation and Recovery Act of 1976 (EPA, 2009). This approach provides a no-impact threshold value for an area of interest based on background groundwater constituent concentrations from wells in a nearby area.

21 The use of the tolerance limit approach in the two case studies discussed here identified a number of 22 issues that will need to be addressed in use of the approach. Although in most cases the TVs were much 23 lower than the regulatory limits, in some cases they were not. In fact, by using an upper tolerance limit 24 for calculation of TVs, it is possible that no-impact thresholds may actually exceed the regulatory limit, as 25 it did for TDS for the High Plains case study. In this case, the identification of a no-impact threshold may 26 still be valuable in allowing one to determine whether additional impact is likely to occur because of a 27 proposed sequestration activity. 
1 A significant issue that needs to be addressed in applying the TV approach based on an upper or lower

2 tolerance limit is the treatment of outliers. Common practice is to exclude outliers from statistical

3 analyses of contaminated groundwater (e.g., Gilbert, 1987; EPA, 2009). However, if there is evidence

4 that the outliers are real, then one can make a case that they should be included in the analysis (EPA

5 2009). In both the Edwards and High Plains case studies, we identified constituents for which outliers are

6 present and appear to be real, i.e., not due to a typographical error or an analytical error. For example, the

7 history of Ba concentrations in well AY-68-28-314 (Fig. 5) shows clear evidence that the high

8 concentration in 2006 for that well is real. If outliers were not excluded from the TV calculations, then

9 the TVs could be much higher for some constituents. For example, if we didn't exclude outliers for

10 calculation of TV for Fe in the Central High Plains Aquifer, then the upper tolerance limit would be about

$11260 \mu \mathrm{g} / \mathrm{L}$, more than an order of magnitude above the TV currently proposed for the High Plains. Thus,

12 the treatment of outliers, especially if there is evidence that the concentrations are real, should be

13 considered carefully, whether the high concentrations are believed to be natural or anthropogenic.

14

15 An important policy question is whether a no-impact threshold is always appropriate in evaluating a

16 proposed $\mathrm{CO}_{2}$ sequestration site. If the groundwater chemistry in an overlying aquifer is much lower than

17 the regulatory threshold, as it was for As in the Edwards Aquifer case study, then a case might be made

18 that some impact on the aquifer could be permitted, if the modeled levels remain well below the

19 regulatory limits. In such a case, a health- or risk-based approach to developing TVs (ITRC 2005) for the

20 expected impact on an aquifer could be examined.

21

22 Another major issue with the approach identified here is the availability of data sufficient to provide

23 reliable statistical results. The approach requires the mean and variance of the groundwater constituent

24 concentrations in wells across the nearby area to be constant (i.e., stationary) and the same as in the area

25 of interest. However, the Central High Plains Aquifer case study illustrates the case where nearby data

26 were not available, so data from a much larger geographic area were used, raising a concern about

27 nonstationarity.

29 Where nonstationarity is an issue, another approach might use non-uniform initial conditions for each of

30 the model grid cells. The use of an "intracell" approach might also be considered for identification of TVs

31 in cells that exhibit significant changes in concentrations over time. This approach may be particularly

32 suitable for study areas where spatial heterogeneity of the input data was found to be significant (e.g.,

33 through the use of ANOVA (EPA, 2009) or geostatistical methods). For example, the use of non-uniform

34 initial conditions would be helpful in cases where outliers are present that appear to be real, as discussed 
1 above. Prior to the modeling runs, locally varying background concentrations would be provided by

2 spatial interpolation (e.g., kriging) of the concentrations at each cell using data collected prior to the time

3 that injection of $\mathrm{CO}_{2}$ begins. Continued monitoring of the time series of concentrations at each cell after

4 injection begins would allow identification of cells where a significant increase occurred, possibly using

5 an approach similar to the Shewhart-CUSUM control chart method described in the EPA Unified

6 Guidance (EPA, 2009).

\section{$\begin{array}{lll}7 & 7 & \text { Conclusions }\end{array}$}

8

9 The use of an "interwell" approach, with an upper or lower tolerance limit with 95\% confidence and 95\%

10 coverage for identifying significant changes to groundwater aquifers predicted by pre-injection modeling

11 of proposed $\mathrm{CO}_{2}$ sequestration appears to hold significant promise. The approach may provide important

12 advantages for screening proposed sequestration sites. Where heterogeneity and/or nonstationarity in

13 groundwater concentrations is significant, a locally varying input coupled with an "intracellular"

14 approach should be explored to establish background for each model cell and to test predicted changes

15 against those background concentrations.

16

17 While the use of existing data can provide some initial insights in to the potential viability of a given

18 location, site-specific data would be needed to establish baseline groundwater quality conditions that

19 capture the spatial and temporal variability of the USDWs prior to $\mathrm{CO}_{2}$ injection and storage. Once

20 monitoring wells have been drilled and tested and injection commences, "intrawell" approaches, similar

21 to those established for RCRA sites (EPA 2009), may be more appropriate for identifying significant

22 impact on aquifer chemistry.

\section{Acknowledgements}

24 This work was completed as part of the National Risk Assessment Partnership (NRAP) Project. Support

25 for this project came from the U.S. Department of Energy's (DOE's) Office of Fossil Energy's Cross-

26 Cutting Research Program. The authors acknowledge Robert Romanosky (NETL Strategic Center for

27 Coal) and Regis Conrad (DOE Office of Fossil Energy) for programmatic guidance, direction, and

28 support. 
1 The authors also acknowledge Christopher Brown of the Pacific Northwest National Laboratory, Preston

2 Jordan of Lawrence Berkeley National Laboratory and Shikha M. Sharma of West Virginia University for

3 their contributions to earlier versions of this study.

4

5 This work was performed under the auspices of the DOE by Pacific Northwest National Laboratory under

6 Contract DE-AC05-76RL01830.

\section{References}

Bacon DH. 2013. Reduced Order Model for the Geochemical Impacts of Carbon Dioxide, Brine and

Bielicki, JM, Pollak, MF, Fitts, JP, Peters, CA, Wilson, EJ. 2014. Causes and financial consequences of geologic $\mathrm{CO}_{2}$ storage reservoir leakage and interference with other subsurface resources. Int. J. Greenh. GasControl 20, 259-273, http://dx.doi.org/10.1016/j.ijggc.2013.10.024.

Benson, SM, Cole DR. 2008. "CO2 sequestration in deep sedimentary formations." Elements 4.5 (2008): 325-331.

Bianchi M, Zheng L, Spycher N, Birkholzer J. 2014. Reduced-order Models for Prediction of Groundwater Quality Impacts from $\mathrm{CO}_{2}$ and Brine Leakage: Application to the High Plains Aquifer. LBNL-6865E, Ernest Orlando Lawrence Berkeley National Laboratory, Berkeley, California.

BRIDGE. 2006. Background cRiteria for the IDentification of Groundwater Thresholds. D14: Report on National Methodologies for Groundwater Threshold Values. 2006. Available at http://www.wise$\underline{\text { rtd.info/en/info/report-national-methodologies-groundwater-threshold-values see also http://nfp- }}$ at.eionet.europa.eu/irc/eionet-circle/bridge/info/data/en/index.htm; accessed 2014-09-09. 
Carroll SA, Keating E, Mansoor K, Dai Z, Sun Y, Trainor-Guitton W, Brown C, Bacon D. 2014. Key factors for determining groundwater impacts due to leakage from geologic carbon sequestration reservoirs. IJGGC, 29 (2014) 153-168.

EPA (U.S. Environmental Protection Agency). 2009. Statistical Analysis of Groundwater Monitoring Data at RCRA Facilities, Unified Guidance. EPA 530/R-09-007, Washington, D.C. Available at http://www.epa.gov/osw/hazard/correctiveaction/resources/guidance/sitechar/gwstats/unifiedguid.pdf; accessed 2014-09-09.

Gibbons, RD. 1994. Statistical Methods for Groundwater Monitoring, John Wiley \& Sons, Inc.: New York; 1994.

Gilbert, RO. 1987. Statistical Methods for Environmental Pollution Monitoring, John Wiley \& Sons, Inc.: New York; 1987.

GWDD. 2006. Groundwater Directive 2006/118/CE, Directive of the European Parliament and of the Council on the protection of groundwater against pollution and deterioration, OJ L372, 27/12/2006; 2006. p. 19-31.

Helsel, DR. 2012. Statistics for Censored Environmental Data Using Minitab and R, 2nd edition; John Wiley \& Sons, Inc.: New York; 2012.

Hepple RP, Benson SM. 2005. Geologic storage of carbon dioxide as a climate change mitigation strategy: Performance requirements and the implications of surface seepage. Environmental Geology 47: 576-585

Herzog, H, Calderia, K, Reilly, J. 2003. An issue of permanence: assessing the effectiveness of temporary carbon storage. Climate Change 59, 293-10, http://dx.doi.org/10.1023/A:1024801618900.2005

IEA (International Energy Agency). 2014. Insights Series 2014, CCS 2014, What lies in store of CCS? International Energy Agency, Paris Cedex 15, France. Available online at http://www.iea.org/publications/insights/insightpublications/ccs-2014---what-lies-in-store-forccs.html; accessed 2015-01-14.

IPCC (Intergovernmental Panel on Climate Change). 2005. Carbon Dioxide Capture and Storage. Intergovernmental Panel on Climate Change, Cambridge University Press, New York. 431 p. 
ITRC (Interstate Technology \& Regulatory Council, Risk Assessment Resources Team). 2005. Examination of Risk-Based Screening Values and Approaches of Selected States. Available at http://www.itrcweb.org/GuidanceDocuments/RISK-1.pdf; accessed 2014-09-09.

Last GV, Murray CJ, Brown CF, Jordan PD, Sharma M. 2013. No-Impact Threshold Values for NRAP's Reduced Order Models. PNNL-22077, Pacific Northwest National Laboratory, Richland, WA. http://www.pnnl.gov/main/publications/external/technical_reports/PNNL-22077.pdf

Lawter S, Qafoku NP, Wang G, Shao H, Brown CF. 2015. Evaluating and Predicting Impacts of $\mathrm{CO}_{2}$ Intrusion into an Unconsolidated Aquifer: 1. Experimental Data. International Journal of Greenhouse Gas Control (Submitted).

Lee L. 2012. NADA: Nondetects and Data Analysis for Environmental Data. R package version 1.5-4. http://CRAN.R-project.org/package=NADA (2012); accessed 2014-09-09.

Musgrove M, Fahlquist L, Houston NA, Lindgren RJ, Ging PB. 2010. Geochemical Evolution Processes and Water-Quality Observations Based on Results of the National Water-Quality Assessment Program in the San Antonio Segment of the Edwards Aquifer, 1996-2006. U.S. Geological Survey Scientific Investigations Report 2010-5129. Appendixes available online at http://pubs.usgs.gov/sir/2010/5129/; accessed 2014-09-09.

McMahon PB, Dennehy KF, Bruce BW, Gurdak JJ, Qi SL. 2007. Water-Quality Assessment of the High Plains Aquifer, 1999-2004; U.S. Geological Survey Professional Paper 1749.

NETL (National Energy Technology Laboratory). 2012. 2012 United States Carbon Utilization and Storage Atlas, Fourth Edition. U.S. Department of Energy, National Energy Technology Laboratory, p. 130. Available online at http://www.netl.doe.gov/research/coal/carbon-storage/atlasiv, accessed 2015-01-14.

Preziosi E, Giuliano G, Vivona R. 2010. Natural background levels and threshold values derivation for naturally As, V, and F rich groundwater bodies: a methodological case study in Central Italy. Environ Earth Sci 2010, 61:885-897.Tukey JW. 1977. Exploratory Data Analysis, Reading, Maine: Addison-Wesley.

USGS (U.S. Geological Survey). 2004. Water Basics Glossary. Available at http://water.usgs.gov/waterbasics_glossary.html\#B; accessed 2014-07-18. 
1 Wang G, Qafoku NP, Lawter AR, Bowden M, Harvy O, Sullivan C, Brown CF. 2015. Geochemical

2 Impacts of Leaking $\mathrm{CO}_{2}$ from Subsurface Storage Reservoirs to an Unconfined Oxidizing Carbonate

3 Aquifer. International Journal of Greenhouse Gas Control (Submitted).

4 Wendland F, Berthold G, BlumA, Elsass P, Fritsche J-G, Kunkel R, Wolter R. 2008. Derivation of 5 natural background levels and threshold values for groundwater bodies in the Upper Rhine Valley

6 (France, Switzerland and Germany). Desalination 2008, 226:160-168.

7 Zheng L, Qafoku NP, Lawter A, Wang G, Shao H, Brown CR. 2015. Evaluating and Predicting Impacts 8 of $\mathrm{CO}_{2}$ Intrusion into an Unconsolidated Aquifer: II. Modeling Results. International Journal of $9 \quad$ Greenhouse Gas Control (Submitted)

10 